\title{
The pedoecologial conditions of natural and opencast peat fields in Estonia
}

\author{
M. Noormets ${ }^{1}$, T. Köster ${ }^{1}$, T. Tõnutare ${ }^{1}$, K. Kauer $^{1}$, R. Kõlli ${ }^{1}$, \\ T. Paal ${ }^{2} \&$ M. Oder ${ }^{1}$ \\ ${ }^{1}$ Department of Soil Science and Agrochemistry, \\ Estonian University of Life Sciences, Estonia \\ ${ }^{2}$ Forest Research Institute, Estonian University of Life Sciences, Estonia
}

\begin{abstract}
Peat soils in five different bog areas were studied during 2004. The study areas were chosen according to their exploitation type; natural, cultivated and milled peatlands. The peat soil nutrient content, plant associations and their nutrient content were examined. The peat soils were analysed for the $\mathrm{C}_{\mathrm{HWE}}$, total $\mathrm{N}, \mathrm{P}, \mathrm{K}$, $\mathrm{Ca}, \mathrm{Mg}, \mathrm{C}$, for ash content and for plant-available $\mathrm{P}, \mathrm{K}, \mathrm{Ca}$, and $\mathrm{Mg}$. For the distribution of nutrients in the peat soils, samples were taken from 0-5, 5-10 and $10-15 \mathrm{~cm}$ depths. The dominating plant species and the type of plant associations were determined in areas where it was presented. The plant samples were analysed for N, P, K, Ca and Mg. The study results showed that in natural peat areas the variability in the ash content was high; the same was found for the $\mathrm{Ca}$ and $\mathrm{Mg}(\%)$ content. With increasing depth, the nutrient content decreased, but this depth relationship was not significant for every parameter examined. The plant cover in cultivated peat areas had the highest nutrient contents.

Key words: Fibri Dystric Histosol, natural peat bog, milled peatland, cultivated peat soils, plant association, total nutrients, available nutrients, $p H, C, N, C: N$ ratio, $C_{H W E}$, ash, $P, K, C a, M g$.
\end{abstract}

\section{Introduction}

Nowadays we consider the peatlands as a valuable ecological biotope that should be protected and rationally used because it is essentially a nonrenewable resource. Currently the peatlands are used for growing wild berry species like: Rubus chamaemorus, Oxycoccus palustris and Vaccinium species [1,2,3]; they 
are used for forestry [4, 5], and as a growing media source for horticulture [6]. Historically and presently, peatlands have been heavily utilized and degraded by their agricultural and mining use. After drainage, the self-regulation system of mires is changed and the natural peat formation process is destroyed and then the dominating process is peat mineralization $[7,8]$. Due to various agricultural activities in peat lands, the peat loss as a result of mineralization could reach 10 to 15 tons of organic material per hectare annually [9]. One possible strategy to stop or slow the mineralization is to cultivate wild berries (Vaccinium species). However, even with this strategy, mineralization and surface deflation are fast compared with peat formation. The preservation of peatland resources is critical because they are reservoirs of clean water, important sinks for carbon sequestration, important for maintenance of the hydrologic regime, and lastly they are valuable biotopes.

The Northern mires represent the largest store of carbon in the terrestrial ecosystem. Therefore, these areas play an important role in the Earth's gas emission budget that affects the atmospheric $\mathrm{CO}_{2}$ concentration. According to Kreshtapova and Maslov [10] the $\mathrm{CO}_{2}$ storage in boreal peat deposits is estimated at $455 \mathrm{Pg}$. Moreover, Horn et al. [11] report that 30\% of global reserves of soil carbon are preserved on natural bog areas. These areas can contribute up to $7 \%$ of the global annual emission of the greenhouse gas methane. If the natural condition of mires is destroyed by drainage, peat harvest, or agricultural use, they will change from being a carbon sink, to an important $\mathrm{CO}_{2}$ emission source.

Currently the annual peat production of different types of peat is approximately $4.5-5$ million $\mathrm{m}^{3}$ in Estonia. Of the produced peat, $2.5-3$ million $\mathrm{m}^{3}$ is comprised of the weakly decomposed peat used as a growing media in various horticultural production operations. The peat for growth substrate is produced mechanically by tractor drawn vacuum machines or by block cut harvesting. Most of the well decomposed peat $\left(1.5-1.8\right.$ million $\left.\mathrm{m}^{3}\right)$ is used for energy consumption. Exports from milled peatlands are in excess of $90 \%$ for plant growing media, $80 \%$ for briquettes, and approximately $60 \%$ for block cut peat [12].

In this article will identify the peat soil properties as found under 'natural' conditions, milled peatland and under the cultivation in order to find out their characteristics and suitability for natural revegetation. An additional purpose of this study was to compare the natural, milled and cultivated peat soils agrochemical properties.

\section{Study area}

The study areas are located in the County of the Tartu, in the southern part of Estonia. According to the WRB soil classification system, the soil of the experimental fields belongs subgroups of Fibri-Dystric Histosols - HSdy(fi). The plant associations of the study areas were determined according to the classification system developed by J. Paal [13]. The study areas Sangla I and 
Sangla III are used currently for peat mining, therefore no plant cover is presented.

Table 1: $\quad$ The type of study area use and plant associations or dominating plant species.

\begin{tabular}{cccl}
\hline $\begin{array}{c}\text { Number of } \\
\text { study area }\end{array}$ & $\begin{array}{c}\text { Name of } \\
\text { study site }\end{array}$ & Type of use & $\begin{array}{c}\text { Plant association or dominating } \\
\text { plant species }\end{array}$ \\
\hline $\mathbf{1}$ & Sangla I & Milled peat land & Without plant cover. \\
\hline $\mathbf{2}$ & Sangla II & $\begin{array}{c}\text { Technogenic } \\
\text { stripe }\end{array}$ & $\begin{array}{l}\text { No clear plant association is } \\
\text { presented }\end{array}$ \\
\hline $\mathbf{3}$ & Sangla III & Milled peat land & Without plant cover. \\
\hline $\mathbf{4}$ & Ilmatsalu I & Natural peat bog & $\begin{array}{l}\text { Ledo-Pinetum, Ledum pine heath } \\
\text { moor }\end{array}$ \\
\hline $\mathbf{5}$ & Ilmatsalu II & $\begin{array}{c}\text { Cultivated peat } \\
\text { bog area. }\end{array}$ & $\begin{array}{l}\text { V. angustifolium, } \\
\text { angustifolium X V. corymbosum }\end{array}$ \\
& & &
\end{tabular}

Sangla I. The peat processing started in this particular area in 1962 and currently the mining area is increased up to 590 ha. The Sangla mire peat deposit thickness is $6.5-9.5 \mathrm{~m}[5,14]$. Before the natural plant cover was removed for mining in Sangla I, the area was characterized as the heath moor growth site type. The main processing commodities produced from this site are horticultural peat and briquettes. For the package peat with the following criteria is used: $100 \%$ of poorly decomposed Sphagnum sp. peat (white peat); the moisture content is between $35 \%$ and $55 \%$; the peat is free of weed seeds and radioactive or chemical substances. The Von Post decomposition index is $\mathrm{H} 1 \ldots \mathrm{H} 3$, the ash content does not exceed $5 \%$; the bulk density is $130-200 \mathrm{~kg} / \mathrm{m}^{3}$; and the $\mathrm{pH}$ is $3.0-4.0$.

Sangla II is a small area surrounding the main peat milling ground where the natural revegetation is occurring and for the purposes of this paper, it is described as a technogenic stripe. The whole area is influenced by drainage and in the past during the planning of the milling ground the plant cover was removed and pushed by machines to the sides. Nowadays there is a succession plant cover that could potentially function as the donor area for wild plant species during the rehabilitation work. The dominating plant species are Pinus sylvestris, Betula sp., and Eriophorum vaginatum. In the grass canopy, the following were identified; Carex cespitosa, C. acuta. C. elata, C. nigra, C. lasiocarpa, Phragmites australis, Phalaris arundinacea, Filipendula ulmaria.

Sangla III. The mining area is located in the Sangla mire (same as the Sangla I peat deposit) and in the Laugesoo mire. The main commodities are fuel peat, peat briquettes and peat extraction.

Ilmatsalu I is part of Sangla mire, named for the region where it is situated. This peat deposit is $6.5-9.5 \mathrm{~m}$ thick (same as Ilmatsalu II) and the bog is classified as heath moor. The somewhat more important plant association of this bog is 
Ledo-Pinetum. The main tree species is Pinus sylvestris with accompanying species of Ledum palustre, Calluna vulgaris, Andromeda polifolia, Empetrum nigrum, Oxycoccus palustri, Vaccinium uliginosum and Vaccinium myrtillus. The following bryophytes were represented Polytrichum commune, P. strictum, Sphagnum sp. In the grass canopy Rubus chamaemorus and Carex sp is presented.

IImatsalu II. In, 1994 the peat milling on current area was finished. Before the peat excavation the growth type was heath moors, and important plant association was Ledo-Pinetum. Currently in opencast peat field have the dominant species Vaccinium angustifolium and in addition $V$. angustifolium $\mathrm{X} V$. corymbosum cultivar Northblue was planted. Randomly among cultivated species appeared Pinus sp., Betula sp. and Eriophorum vaginatum. In the bryophyte canopy Marchantia polymorpha, Ceratodon purpureus, Polytrichum strictu, Funaria hygrometrica are randomly scattered. Drosera rotundifolia was randomly found. In early spring the plantation received $50 \mathrm{~kg} \mathrm{ha}^{-1}$ of $(11: 11: 22)$ $\mathrm{N}: \mathrm{P}_{2} \mathrm{O}_{5}: \mathrm{K}_{2} \mathrm{O}$ fertilizers.

\section{Materials and methods}

For the current investigation the soil sampling was carried out during the vegetation period in 2004 . The plant association description was made during the summers of $2004-2005$. Soils were described on the basis of test pits and the samples for analysis were taken from different depths $(0-5,5-10$ and 10-15 cm). The peat soil samples were taken in four replicates and analysed in laboratory in triplicate. Peat samples were analysed for organic $\mathrm{C}$ according to the Tjurin method [15] and total $\mathrm{N}$ according to Kjeldahl [16]. For the direct estimation of the organic matter content the loss-on-ignition (LOI) method was used. Available $\mathrm{P}, \mathrm{K}, \mathrm{Ca}$ and $\mathrm{Mg}$ were analysed according to the Mehlich-3 method [18]. The $\mathrm{pH}$ was measured from the soil suspension with $1 \mathrm{M} \mathrm{KCl} \mathrm{(1:5} \mathrm{w/v).} \mathrm{For}$ the total phosphorus, potassium, sodium, calcium and magnesium in peat and plant determination samples were destroyed by wet digestion with sulphuric acid. Total phosphorus was determined spectrophotometrically by vanadomolybdophosphoric acid method. $\mathrm{K}, \mathrm{Ca}$ and $\mathrm{Mg}$ were determined with atomic absorption spectrometer [17]. Hot water extractable organic $\mathrm{C}$ from the soil-water extract $(1: 100, \mathrm{w} / \mathrm{v})$ was measured [16]. STATISTICA 7 [19] was used for the statistical analysis and the standard error $( \pm \mathrm{SE})$ is presented on the figures. In the tables the standard deviation $( \pm \mathrm{SD})$ is presented.

\section{Results and discussion}

The study area peat $\mathrm{pH}$ values varied from 2.4 to 5.2. In Sangla III the $\mathrm{pH}$ was relatively high ( $\mathrm{pH}$ 5.2) it might be hypothesized that the higher values for $\mathrm{pH}$ and ash are indicative of the increased importance of fen deposit. However, the nutrient content is low at this location. Spiers [20] is found that in low acidic

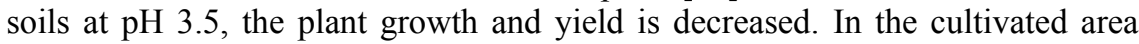


Ilmatsalu II despite to fertilizers application the soil nutrient content for total and available nutrients was low when compared to other areas (Table 2).

Table 2: $\quad$ Peat soils agrochemical properties in the study areas $(n=12)$.

\begin{tabular}{|c|c|c|c|c|c|}
\hline \multirow{2}{*}{$\begin{array}{c}\text { Soil } \\
\text { characteristic }\end{array}$} & \multicolumn{5}{|c|}{ Number of study area } \\
\hline & 1 & 2 & 3 & 4 & 5 \\
\hline $\mathrm{pH}_{\mathrm{KCl}}$ & $4.0 \pm 0.7$ & $4.0 \pm 0.7$ & $5.2 \pm 0.1$ & $2.4 \pm 0.1$ & $3.1 \pm 0.9$ \\
\hline $\mathrm{C}_{\text {tot. }} \%$ & $38.9 \pm 2.4$ & $38.3 \pm 3.3$ & $38.3 \pm 3.1$ & $38.4 \pm 4.4$ & $41.0 \pm 2.9$ \\
\hline $\mathrm{N}_{\text {tot }} \%$ & $1.3 \pm 0.3$ & $1.6 \pm 0.2$ & $2.1 \pm 0.1$ & $1.0 \pm 0.3$ & $1.0 \pm 0.1$ \\
\hline $\mathrm{C}: \mathrm{N}$ & $31.5 \pm 10.2$ & $24.4 \pm 2.6$ & $18.3 \pm 2.3$ & $40.7 \pm 12.9$ & $42.3 \pm 7.6$ \\
\hline $\mathrm{C}_{\mathrm{WE}} \cdot \%$ & $0.62 \pm 0.16$ & $1.75 \pm 0.44$ & $0.5 \pm 0.1$ & $1.1 \pm 0.4$ & $1.0 \pm 0.3$ \\
\hline Ash \% & $3.3 \pm 1.6$ & $27.1 \pm 18.6$ & $10.7 \pm 4.7$ & $3.3 \pm 2.9$ & $1.3 \pm 0.6$ \\
\hline $\mathrm{P}_{\text {tot. }} \%$ & $0.03 \pm 0.01$ & $0.05 \pm 0.01$ & $0.03 \pm 0.02$ & $0.03 \pm 0.02$ & $0.02 \pm 0.01$ \\
\hline $\mathrm{K}_{\text {tot. }} \%$ & $0.19 \pm 0.05$ & $0.64 \pm 0.24$ & $0.14 \pm 0.13$ & $0.29 \pm 0.25$ & $0.11 \pm 0.08$ \\
\hline $\mathrm{Ca}_{\text {tot. }} \%$ & $0.7 \pm 0.2$ & $0.7 \pm 0.2$ & $1.2 \pm 0.4$ & $0.2 \pm 0.1$ & $0.4 \pm 0.3$ \\
\hline $\mathrm{Mg}_{\text {tot. }} \%$ & $0.18 \pm 0.05$ & $0.26 \pm 0.10$ & $0.23 \pm 0.03$ & $0.06 \pm 0.01$ & $0.12 \pm 0.08$ \\
\hline $\mathrm{P}_{\mathrm{avb}} \cdot \mathrm{mg} \mathrm{kg}^{-1}$ & $23.5 \pm 10.4$ & $85.6 \pm 36.9$ & $8.9 \pm 4.8$ & $88.3 \pm 85.8$ & $34.8 \pm 31.7$ \\
\hline $\mathrm{K}_{\mathrm{avb}} \cdot \mathrm{mg} \mathrm{kg}^{-1}$ & $224.8 \pm 86.4$ & $207.2 \pm 56.9$ & $120.2 \pm 19.7$ & $297.4 \pm 129.5$ & $190.8 \pm 34.5$ \\
\hline $\mathrm{Ca}_{\text {avb. }} \mathrm{mg} \mathrm{kg}^{-1}$ & $9258 \pm 1375$ & $9070 \pm 2410$ & $12889 \pm 2319$ & $3530 \pm 959$ & $5551 \pm 1988$ \\
\hline $\mathrm{Mg}_{\text {avb. }} \mathrm{mg} \mathrm{kg}^{-1}$ & $1598 \pm 328$ & $1840 \pm 381$ & $1733 \pm 217$ & $766 \pm 248$ & $1253 \pm 567$ \\
\hline
\end{tabular}

*tot- total content of nutrients, *avb- available content of nutrients.

*The numbers in tables are presented as average of different depths (upper $15 \mathrm{~cm}$ ).

According to the soil nutrient assessment valuation done at Estonian Agricultural Research Centre the content of plant available P is in Sangla I and Ilmatsalu II low (23.5 and $34.8 \mathrm{mg} \mathrm{kg}^{-1}$, respectively), in Sangla III very low (8.9 $\mathrm{mg} \mathrm{kg}^{-1}$ ). Unexpectedly, the content of available $\mathrm{Ca}$ and $\mathrm{Mg}$ was very high in all study areas peat soils.

The plant nutrient content was higher in the cultivated area than on natural area grown plants (Figure 1). Although, the agrochemical parameters of the cultivated area were in the same range, or slightly lower, the plant nutrient content was higher. It is reported that the availability of $\mathrm{P}$ could be enhanced while the yield is decreased [21]. But Holmes [22] has indicated that this situation could be improved by additional phosphorous application. Fertilization of plants grown in peat soils is important [23, 24, 25] because of the low mineral nutrient availability in soil. From Noormets et al. [26] in a study using Vaccinium species have found that plant growth and yield formation on opencast peat field (Fibri Dystric Histosol) was influenced by the fertilisation rates and nutrient balance at $\mathrm{pH}$ level 2.8-4.0.

Significantly different content for total $\mathrm{N}$ and $\mathrm{Ca}$, also available $\mathrm{Mg}$ was found in milled peatland when compared to the milled and cultivated peatlands (Figure 1). The natural peat soils were found to have higher levels of total $\mathrm{K}$ and plant-available $\mathrm{P}$ and $\mathrm{K}$ when compared to mined locations. The content of ash depended upon the decomposition level of peat material itself, and it varied from $3.3 \%$ to $27.1 \%$ in the areas examined. The higher content of ash in technogenic stripe might be explained by the mineral material that is carried from the road 
nearby. Some studies have found that the liming of peat soils could lead to the $\mathrm{pH}$ increase but in natural areas, like an exhausted peat soil, it could increase the possibility for the wild plant species expansion from the surrounding areas [27]. The revegetation of milled peat lands areas in Estonia with trees and bushes occurs rapidly, but the restoration of natural Sphagnum mosses would seem to be very complicated. According to Salonen [28] the plant succession in opencast peat fields differs from the natural sites. As demonstrated in trials in the Cacouna Station (Canada), the revegetation in some plots by trees and bushes occurred very quickly. The scarcity of Sphagnum and other mosses indicates that the bog is not returning to the functional peatland ecosystem [29]. The revegetation depends on the peat harvesting technology, where the block-cut mined bogs were rapidly recolonized (less than 5 years) by ericaceous shrubs, but the vacuummined peatlands were covered by plant cover much more slowly (approximately 25 years) and not by typical peatland species. The study has pointed to the two main problems occurring by revegetation: firstly, large areas are without any plant cover; and secondly, the moisture deficiency in the top peat layers. Both of these conditions contribute to the wind erosion of the peatland [29].

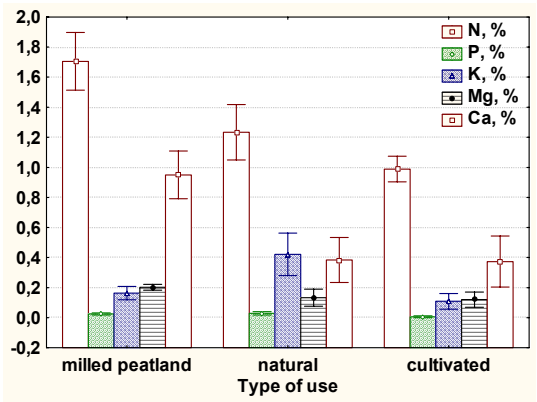

A.

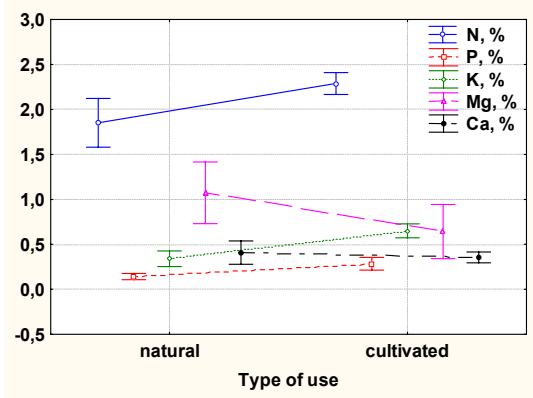

C.

Figure 1: The nutrient content of different investigation areas according to the type of exploitation $(\mathrm{M} \pm \mathrm{SE})$. A- content of total nutrients. Bcontent of available nutrients. C- content of total nutrients in plants. D- content of total carbon and ash.

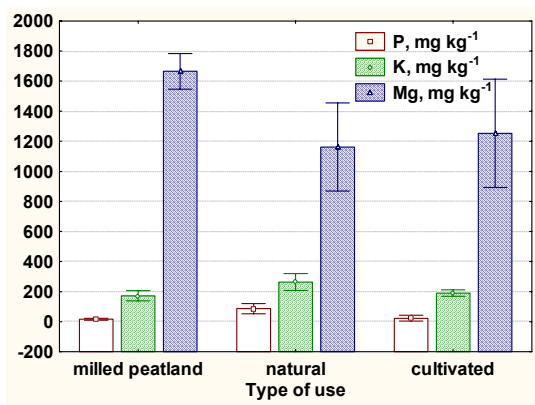

B.

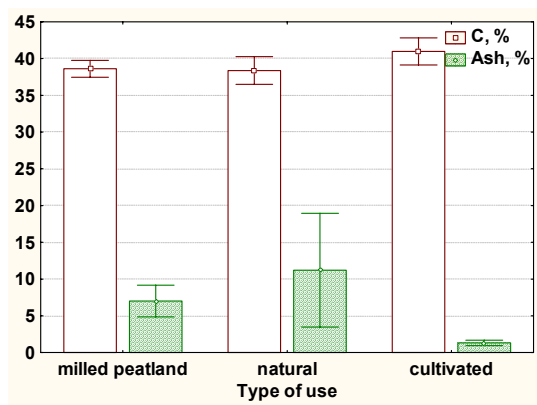

D. 


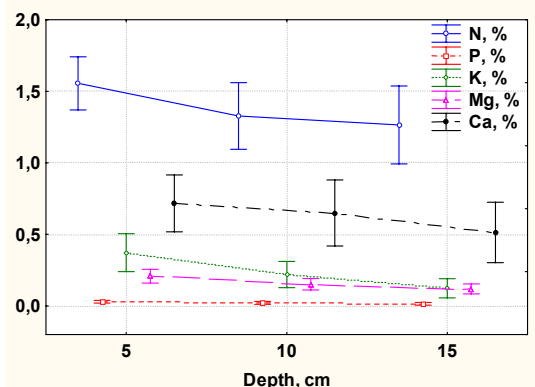

A.

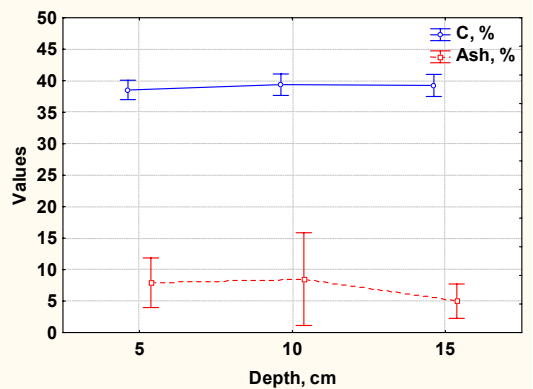

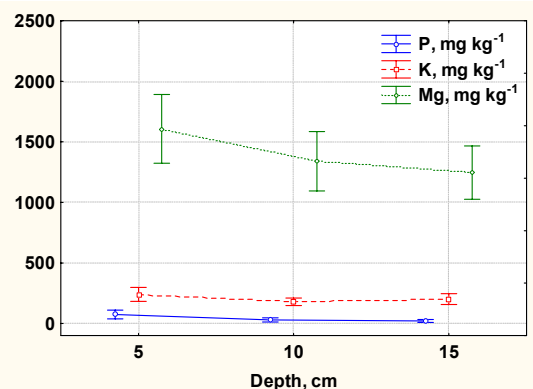

B.

$$
\text { C. }
$$

Figure 2: The nutrient content in different depths $(\mathrm{M} \pm \mathrm{SE})$. A- the content of total nutrients. B- the content of available nutrients. C- content of total carbon and ash.

The mean content of some nutrients $\left(\mathrm{N}_{\mathrm{tot}}, \mathrm{Ca}_{\mathrm{tot}}, \mathrm{Mg}_{\mathrm{avb}}\right)$ decreased with increasing depth, but as the variability was high, this decrease was not significant (Figure 2). However, the decrease of some nutrient by depth like $\mathrm{K}_{\text {tot }}$ and $\mathrm{Mg}_{\text {tot }}$ was observed. Also, there was found to be a significant decrease in the content of $\mathrm{P}_{\mathrm{avb}}$.

\section{Conclusions}

Currently, in Estonia there is a tendency to expand the working milling areas of peatlands and then the rehabilitation work is completed afterward. This study has demonstrated that the content of available $\mathrm{P}$ was highly variable, ranging from $10-88.3 \mathrm{mg} \mathrm{kg}^{-1}$, and the variability was highest in natural bog areas. In the technogenic stripe areas, the ash content $(27.1 \%)$ was significantly higher than in other study areas where it ranged $1.3-3.3 \%$. The content of available $\mathrm{Ca}$ and $\mathrm{Mg}$ was also very high. The nutrient content in the plant cover was higher than in natural area, likely due to fertilization. The studied depths for nutrient content in the peat deposit showed significance difference for total $\mathrm{K}$ and available $\mathrm{P}$, for the rest of parameters the variability found to be very high. 


\section{Acknowledgements}

We thank colleagues from the Department of Soil Science and Agrochemistry EMU for their collaboration with the laboratory analyses, especially Mrs. Imbi Albre. We thank the farmers and companies for their kind permission to use their property for the research. This study was supported by the Estonian Ministry of Education and Research, No 0172613s03. The conference participation fee was supported by RAK and by the Estonian Science Foundation (Project 4726).

\section{References}

[1] Noormets, M., Köster, T., Karp, K., Paal, T. \& Tõnutare, T., The recultivation of opencast peatland in Estonia. Proc. of the 12th International Peat Congress. Wise Use of Peatland. ed. J. Päivänen, Finland, pp. 1195-1201, 2004.

[2] Jaadla, T., Cranberry production on peatlands. Estonian Peat, 1, pp. 19, 1994.

[3] Paal, T., On cultivating European cranberry in Estonia. Journal of Small Fruit and Viticulture. 1(1), pp. 59 - 61, 1992.

[4] Hartman, M., Karisto, M. \& S. Kaunisto. Carbon dynamics for a drained peatland forest with drainage and nutrition gradients. Ecohydrological Processes in Northern Wetlands. pp. 209-214, 2003.

[5] Valk, U., Estonian mires. Valgus, Tallinn-Estonia, pp. 270, 1988.

[6] Carlile, W.R., Horticultural developments, environmental challenges and growing media. A global perspective. Proc. Int. Conf. Peat in Horticulture, Quality and Environmental Callenges, eds. G. Shmilewski. \& L. Rochefort, Estonia, pp. 17-23, 2002.

[7] Ilomets, M., The peat mining on account of what? Estonian Nature, 2/3, pp. 20-24, 2003.

[8] Armentano, T.V. \& Menges, E.S., Patterns of change in the carbon balance of organic soil wetlands of the temperate zone. Journal of Ecology, 74, pp. 755-774, 1986.

[9] Tomberg, U., Breakdown of peat as a result to drainage, Saku, Estonia, pp. 32, 1992.

[10] Kreshtapova, V., N. \& Maslov, B. S., Contents of carbon compounds in reclaimed peat soils as a function of the properties of peat organic matter. Proc. of the $12^{\text {th }}$ Int. Peat Congr. Wise Use of Peatland. ed. J. Päivänen. Finland, 2, pp. 988-992, 2004.

[11] Horn, M.A., Matthies, C., Küsel, K., Schramm, A. \& Drake, H.L. Hydrogenotrophic methanogenesis by moderately acid-tolerant methanogens of a methane-emitting acidic peat. Applied and Environmental Microbiology, 69, pp. 74-83, 2003.

[12] Estonian Competition Board, 2002. http://www.konkurentsiamet.ee/ dokumendid/ko200272.htm.

[13] Paal. J., Classification of Estonian vegetation site types. Tartu-Tallinn. pp. 297, 1997. 
[14] Orru. M., Širkova. M. \& Veldre. M., Estonian peat resources. Estonian Geological Survey. Tallinn, pp. 146, 1992.

[15] Vorobjova, L.A., Chemical analysis of soils. Textbook, Moscow University Press, pp. 272, 1998.

[16] Procedures for soil analysis, ed. L.P. van Reeuwijk Wagening: ISRIC, pp. $112,1995$.

[17] Methods of soil analysis. Part 3. SSSA Book Series: 5. Madison. Wisconsin. USA. pp. 1390, 1996.

[18] Handbook on Reference Methods for Soil Analysis. Soil and Plant Analysis Council. Inc. pp. 202, 1992.

[19] Statsoft. Statistica 7,0. Copyright 1984-2005.

[20] Spiers, J.M., Influence of lime and sulfur soil additions on growth, yield and leaf nutrient content of rabbiteye blueberry. Journal of the American Society of Horticultural Science, 109, pp. 559-562, 1984.

[21] Bishko, A.J. \& Fisher, P.R., The pH-Response of a Peat-based Medium to Application of Acid-reaction Chemicals. Horticultural Science, 38(1), pp. 26-31, 2003.

[22] Holmes, R. S., Effect of phosphorous and ph on iron chlorosis of the blueberry in water culture. Soil Science, 90, pp. 374-379, 1960.

[23] Noormets. M. \& Karp. K., The influence of fertilization to vegetative growth of the lowbush blueberry (Vaccinium angustifolium Ait.) in a young and cropping plantation in peat bog. Transactions of the Estonian Agricultural University, 212, pp. 149 - 154, 2001.

[24] Noormets, M., Karp, K., Starast, M. \& Paal, T., The influence of fertilization on the production of lowbush blueberry (Vaccinium angustifolium Ait.) seedlings on opencast peat pits. Journal of Agricultural Sciences, 5(8), pp. 293-303, 2002.

[25] Noormets. M., Karp. K. \& Paal. T., Recultivation of opencast peat pits with Vaccinium culture in Estonia. Ecosystems and Sustainable Development $I V$. eds. E. Tiezzi. \& C.A. Brebbia. Wessex Institute of Technology. UK and J-L. USO. Universitat Jaume I. Spain. 2, pp. 584, 2003.

[26] Noormets, M., Karp, K., Kelt, K.,Tõnutare, T. \& Paal, T., Fertilizers effects on the lowbush blueberry (Vaccinium angustifolium Ait.) plants and berry chemical composition, grown in opencast peat pits. Journal of Agricultural and Food Science, (submitted), 2006.

[27] Paal, T., Starast, M. \& Karp, K., The influence of liming on growth of lowbush blueberry on exhausted peat fields. Uprawne rosliny wrzosowate, ed. T. Ligocka, Skiernewice, Poland, pp. 71-76, 2003.

[28] Salonen. V., Penttinen. A. \& Särkkä. A., Plant colonization of a bare peat surface: population changes and spatial patterns. Journal of Vegetation Science 3, pp. 113-118, 1992.

[29] Lavoie. C. \& Rochefort. L., The natural revegetation of a harvested peatland in southern Quebec: A spatial and dendroecological analysis. Ecoscience 3(1), pp. 101-111, 1996. 
422 Geo-Environment and Landscape Evolution II

[30] Naucke, W., Heathwaite, A.L., Eggelsmann, R. \& Schuch, M., Mire chemistry. Mires. Process, exploitation and conservation. ed. Heathwaite, A.L. pp. 263-310, 1993. 